together with many excellent line drawings. Botanists and foresters will note with interest an observation on the flowering of bamboos in Malaya. In the equable climate which prevails there, the simultaneous, gregarious flowering of single species in particular areas, sometimes at intervals of several years, which is a well-known phenomenon in India, apparently does not occur. On the contrary, the native Malayan species can continue to grow indefinitely, flower sporadically from time to time, or in some instances, flowering a little almost continuously; the gregarious dying-back after a heavy flowering, as in India, is at most only an occasional feature of the Malayan scene. Among others, an item of considerable interest is a close analysis and comparison of the inflorescences in bamboos and grasses.
In revising the Myristicaceae, Sinclair has pointed out that a regional flora of this group, as, indeed, of any other group, is likely to be unsatisfactory unless it is seen against the considerably wider background of the species present in the whole of the adjacent Malaysian region. Thus, many species formerly considered to be confined to Malaya are now known to occur in Sumatra and Borneo. The difficulties encountered in the systematic treatment of the group are discussed. In the present revision, 53 species, 5 varieties and 1 form are deseribed, whereas, in Ridley's "Flora", the equivalent numbers were 45 species and 4 varieties. Six new species are described. The text is well illustrated with line drawings and with photographs showing bark characters.

\title{
AMERICAN ARACHNIDA
}

$\mathrm{T}$ HE spider family Dictynidæ has only recently been separated from the allied Amaurobiidæ, and its North American species are here revised and described. It is a family of world-wide distribution, with more than thirty genera and three hundred species, predominantly found in the north temperate zone. A dozen are British.

The spiders themselves are small spinners of cribellate webs in a variety of situations, and are unusual in that many species are gregarious, living together in very large numbers. In some areas in the States their thick communal webs choke ornamental conifers and evergreens and so give the spiders an economic importance. Their general habits and mode of life are but little known, and of their courtship and mating even less has been described. As a whole they seem to belong to the spring and summer, at which season alone males are to be found. The females lay only a few eggs, enclosed in lenticular cocoons, which are hung in the webs.

A recent paper by Prof. R. V. Chamberlin and W. J. Gertsch* describes eight American genera and 159 species, 119 of which are placed in the genus Dictyna. All these are fully described with the close attention to detail that modern arachnology requires, and distribution maps are added for many of the commonest species. The paper ends with 47 plates, carrying more than 600 admirable drawings, the work

* Bulletin of the American Museum of Natural History. Vol. 116, Article 1 : The Spider Family Dietynidae in America North of Mexico. By Prof. Ralph V. Chamberlin and Willis J. Gertseh. Pp. 1-152+ plates 1-47. (New York: American Museum of Natural History, 1958.) 3.50 dollars. of Miss Marjorie Statham, whose artistry has enriched so many recent publications from the American Museum of Natural History.

It is obvious that this is one of the most painstaking revisions of a family of spiders that has appeared in recent years, and the authors must be congratulated on their achievement. At the same time its true significance can be properly judged only if two other points are mentioned. The first is that the authors themselves describe the revision as "still in many ways a preliminary one", since very large collections of Dictynidx are now held both in New York and Utah. Here is an indication of the amount of systematic work which even a single family of spiders may involve.

The second point is that this paper recalls others, comparable if not quite so large, lately published in the Bulletin of the American Museum of Natural History. Dr. Levi's revision of the genus Enoplognatha and Dr. Muma's survey of American Solpugida are conspicuous examples. These have been supplemented by the smaller but no less desirable publications in the lively series, now some two thousand in number, called American Museum Novitates. No fewor than twenty-six of these, all dealing with the systematic side of arachnology, have come into my laboratory during the past few years. Obviously, there is a vigorous and fertile school of arachnology in America, which is taking its share, and more, in the very considerable task of ordering the Arachnida of the world in a coherent, reliable and accurate system. Theodore SAvORY

\section{OXYGEN AS A PREREQUISITE TO THE ORIGIN OF THE METAZOA}

\author{
By Dr. J. R. NURSALL
}

Department of Zoology, University of Alberta, Edmonton, Alberta

$\mathrm{D}^{2}$ URING recent years there has been a revival of interest in the problems of the origin of life. This has led to speculation and experimentation, mostly along biochemical and biophysical lines. Less attention has been focused on the problems of the next steps in organic evolution, namely, those attending the diversification of primitive living forms into the kingdoms of organisms recognized to-day.

One of the important questions concerns the sudden appearance of highly organized metazoans in the fossil record. To state this more specifically : Why are there no fossil records of animal life from earlier 